\title{
Traditions, Festivities and Finales: The Changing Role and Reception of the Downton Abbey Christmas Special
}

Andrea Wright

Edge Hill University

\begin{abstract}
:
The popularity of Downton Abbey (2010-2015), especially its international success, has fascinated and divided commentators and journalists. Subsequently a growing American audience, which culminated in record viewing figures for the fourth season, encouraged discussion of what the appeal of the show might be (PBS Press Release 2014). Importantly, the increased trans-Atlantic demand impacted upon the programme's content and can be charted most obviously via the 'Christmas specials'. These feature length episodes were first screened on Christmas Day in the UK and acted as a season finale for American viewers in February. The first was a hyperbole of Christmas past which was enthusiastically received by the British press. Romance in the snow, a ghost, and bustling festivities suited the 25 December screening, but was out-of-season across the Atlantic and, as Derek Johnston has noted, the inclusion of a supernatural element struck some US reviewers as odd (Johnston 2015: 86). The subsequent specials have been less seasonally related, with the 2014 and 2015 episodes only returning to a Christmas setting at the end and, although strongly reliant on traditions and nostalgia, seem far more mindful of US scheduling. Interestingly, they have also gained less praise from the British press. This article will consider the shifting themes and tone of the Downton Abbey Christmas special and the British and American critical reception in order to explore the challenges of negotiating domestic and international appeal.
\end{abstract}


Keywords: Downton Abbey, Christmas, seasonal special, season finale, nostalgia, critical reception, negotiation

The popularity of Downton Abbey (2010-2015), especially its international success, has fascinated and divided commentators and journalists. A growing American audience, which culminated in record viewing figures for the fourth season, encouraged discussion of what the appeal of the show might be (PBS Press Release 2014). As a co-production between UK production company Carnival Film and Television and the US Masterpiece Theatre, this transatlantic appeal was certainly recognised. However, the level of US interest was unprecedented, with the resulting negotiations of the differing demands of the two audiences most obvious in the 'Christmas specials'. These feature length episodes were screened on Christmas Day in the UK and acted as a season finale for American viewers in February. But, as Jordan Bartel observed, this was sometimes a difficult concession:

The 'Downton Abbey' Christmas specials are a funny thing. First of all, they're billed as the season finale in America, when, in the U.K., they really aren't. Instead they, you guessed it, air on Christmas day. As a consequence, many of the penultimate season episodes come across as finales in America. In the next-to-last episodes, there are often cliffhangers (ex from this season: Anna's arrest or, in Season 2, Bates arrested for his ex-wife's death) or pleasant plot resolutions (Mary discovering that she can now have children in Season 3). The Christmas special can sometimes feel like an afterthought — pleasant enough at best, anticlimactic at worst. (Bartel 2015)

This article will consider the shifting themes and tone of the Downton Abbey Christmas special and the British and American critical reception to explore the challenges of negotiating domestic and international appeal. Moreover, it will consider how mediating these dominant markets required the episodes to simultaneously function as seasonal special 
and season finale, thus exposing the difficulties inherent in trying to meet the expectations of both.

For British broadcasting the festive special is a usually a one-off episode of a programme not usually scheduled during the Christmas period or perhaps one that no longer exists as a frequently running series. It is this 'event' nature that is a markedly special occasion for viewers. The Christmas special is distinct because it can also take familiar characters out of their customary situations and settings. The themes of such shows, although not necessarily seasonally-set, may be overtly celebratory or deliberately dark, and indeed may well oscillate between warmth and hope and isolation and despair in a single episode. For example, BBC One's Call the Midwife (2012- ) 2015 Christmas special featured a carol service put in jeopardy by an outbreak of measles, the disappearance of a vulnerable regular character, a surprise birth for an aging couple and a reunion. Whether explicitly Christmasthemed or not, the British television specials appear to endorse a spirit of the season by either bringing people together or by highlighting the plight of others in what should be a season of goodwill and joy. Even the tradition of ghost stories at Christmas, as noted by Derek Johnston, could be read as 'safe space in which to confront fears in way that is beneficial to the individual' (Johnston 2015: 3).

Functioning as part of a series, the season finale has a somewhat different task. Felix Brinker highlights the conventions that have been established by serial television and suggests that the programmes employ 'audience management' strategies, specifically, '[as] a cultural form whose central function is the promotion of itself and its carrier media, series aim to engage their audiences repeatedly and on a regular basis' (Brinker 2015: 50). To keep the viewers' attention over a prolonged period the series employ a range of devices 'that alert the viewer to what has happened before and to what might happen next' (Brinker 2015: 50). 
This ensures that the audience is orientated and immersed in on-going storyline. As well as maintaining continuity, the series must also deliver bombshells and revelations, and as Brinker observes, 'surprising plot twists and moments of heightened suspense, along with teasers for upcoming episodes at the end of episodes, serve to direct the audiences' attention to the future of the narrative and create expectations for the events to come' (2015: 51). In a long-running series such as Downton Abbey the episode that is screened as a season finale and a festive special has an especially tricky negotiation to make. On the one hand, it must serve the needs of the series and provide impetus for the viewers to tune into the next season, but on the other it must satisfy the expectations of seasonal programming. Moreover, it is also under consistent scrutiny from critics and reviewers.

Since the beginning of the series in 2010, critical responses to Downton Abbey ranged from celebratory to scathing. The show's nostalgic representation of a British aristocratic family coming to terms with the rapidly changing world of the twentieth century, their romantic and familial entanglements and the upstairs and downstairs interactions of the household filled with drama, jollity and tragedy placed it firmly within the realms of 'quality' Sunday evening television in the United Kingdom. As Estella Tincknell has observed,

[n]otably Downton Abbey has been consistently represented in reviews through the 'feminine' discourses of cosiness, predictability and craftsmanship rather than the 'masculine' tropes of risk, adventure and the cultural assault of high art, especially when it has been under attack. Characteristically, then, the status of 'Sunday treat' viewing opens it up to accusations of sentimentality and superficiality, familiar cultural features of the feminine. (2013: 774)

Tincknell draws attention to historian Simon Schama's derisive piece in Newsweek published following the US airing of season two. Schama objected to the sugar-coated, conceited 
representation of the past and attributed its success with American audiences to escapism (2012: 12). Such observations were reinforced by A. A. Gill's acerbic review for The Sunday Times: 'As a format and a concept, it is everything I despise and despair of on British television: National Trust sentimentality, costumed comfort drama that flogs an embarrassing, demeaning and bogus vision of the place I live in’ (2011).

Creator Julian Fellowes has been unapologetic about the content and format of his series and in an interview for Vanity Fair cited soap opera as a significant inspiration for his work (Kamp 2012). Moreover, he seemed content to embrace the label 'melodrama' (which the interviewer David Kamp notes was at odds with other popular programming of 2012, such as Mad Men [2007-2015] and Breaking Bad [2008-2013]), and even suggested that Downton Abbey perhaps had stronger ties to The Waltons (1971-1981) in terms of its 'nice' characters (Kamp 2012). For James Chapman, it is precisely this relaxed comingling of generic tropes that made Downton Abbey a reinvention of the British costume drama. He argues that the conventions of studio-based drama, costume drama and soap opera were all at work in the series and contributed to its appeal and success (Chapman 2014: 138-141). On a more fundamental level the way in which costume dramas operate in bringing together familiar aspects from the present (in this instance recognisable genre conventions) and a recreated version of the past exposes the complexities at work in such texts. Jerome de Groot argues that the "reader/audience/viewer is constantly aware of the "difference" of the narrative whilst simultaneously understanding that this pastness is itself a falsification' (2009: 182). Paradoxically this means that the text is at once 'self-consciously theatrical' and "“authentic" in its presentation of the past and performing that past as if it can ignore its status as something in the present' (de Groot 2009: 182). Fellowes appeared to be acutely aware of this paradox and comfortable in exploiting it within the series and the seasonal episodes, but it seems to have been more problematic for critics. 
The scrutiny of the costume drama is perhaps intensified in this case because of the need to manage the dual function of the Christmas specials/season finale. Indeed, the critical reception of the seasonal episodes is a particularly useful because it charts responses to the shows and demonstrates how the programme makers have responded in their attempts to cater to international audiences. Therefore, each of the seasonal episodes and their popular critical reception, first in the UK and then the US, will be explored in detail.

\section{'Christmas at Downton Abbey' (2011)}

The first special, screened after the second season, seems the most overt attempt to court the British audiences and critics using the comforting and 'feminine' attributes identified by Tincknell. It also contains the complex pleasures of the recognisable and the different alluded to by de Groot. Season two was uneven and compromised by a crowded plot and confusingly rapid pace, but the festive special slowed and revelled in nostalgia for Christmases past.

The episode opens with a suitably cold and misty-looking scene as a van makes its way through the estate to deliver an enormous tree. A montage of bustling servants and the family decorating the tree follows and a caption announces that it is Christmas 1919. The mood is tempered, however, with thoughts of Bates (Brendan Coyle), Lord Grantham's (Hugh Bonneville) valet, who has been arrested for the murder of his ex-wife, and a cut reveals his solitude as he awaits trial in a dismal cell. The family's dinner has a determined focus on traditions from a flaming pudding to playing 'The Game', a diversion like charades. Below stairs lady's maid O'Brien (Siobhan Finneran) and two housemaids set up a planchette set that kitchen maid Daisy (Sophie McShera) discovered earlier in the servants' hall thus, with the inclusion of a potential supernatural element, affirming the distinctly British television festive customs. 
Fellowes spoke enthusiastically about incorporating very personal nostalgia for Christmas in an interview in the Radio Times. He stated explicitly that, 'I have barefacedly based Christmas at Downton on those of my own childhood' and deliberately drew on memories of the look and atmosphere of the festive season with wood panelling, open fires, a huge tree and the coming together of family and friends (Fellowes 2011). Such indulgences are fittingly cosy and reassuringly romantic, and respond accordingly to the episode's UK scheduling, but they also reveal something more fundamental about the nature of representations of Christmas within popular culture. Sheila Whiteley observes that ' $[\mathrm{t}] \mathrm{he}$ emphasis on harmony, hearth and home versus the bleakness of the outside world is ideologically powerful' (2008a: 2). This, she continues, is despite the contradictions, such as loneliness, commercialization and the constructed nature of the season espoused by the media. Moreover, even though the religious foundations of the period have limited meaning in diverse contemporary Britain:

$[\ldots]$ the associated sentiments of harmony and goodwill continue to provide an ideological discourse that informs its popular interpretation: a concern for the family, children and family-centred activities, rituals and expectation framing gift-giving and receiving, and an idealised nostalgia for the past, which prioritises themes of neighbourliness, charity and community. (Whiteley 2008a: 2)

Whiteley suggests that there are distinctive features and specific expectations surrounding Christmas texts. This is similarly affirmed by Robert J. Thompson who has argued that Christmas programming on American television is based on a 'nexus of traditions' that, despite popular culture's secularization of the period, celebrates a Christian festival (2005: 46). Thompson elaborates that: 
[i]nstead, the specials contain the vague trappings associated in the popular imagination with religious life: traditional values, moral living, nostalgia. Christmas programming in general is nearly always characterized by a very heavy emphasis on the home and the extended family, and on the virtue of generosity. (2005: 48)

Ultimately, for Thompson, there is a cynical consumer drive at the heart of much of the gift giving and a festive glow cultivated by the shows, a perhaps undeniable tension that exists in popular and consumer culture, but, nevertheless, his, and indeed Whiteley's, emphasis on family, tradition and an underlying spirit of Christmas seems congruent with Fellowes's own sensibilities. It is also a comingling of what appears to be a common, contemporary understanding of the sentiments of Christmas and a highly-stylised version of history. However, the concord between Whitely and Thompson regarding the content of Christmas programming renders the 2011 special problematic for its US scheduling because the themes and tone of the episode explicitly incorporate the agreed spirit of the season, and yet it was screened February.

The episode indulges the notions of family, community and charity and, in dramatic terms, each storyline is played out to a satisfying conclusion, thus further underscoring the comforting tone of the episode. As a special episode, it operates particularly well, but it is lacking the 'what happens next?' drive of a season finale. Most significantly, though, the simmering romance between Mary and Downton heir Matthew (Dan Stevens) provides the episode's climactic moment, thus further emphasising romantic themes of happiness and familial unity. Despite the early scepticism and playful manipulation of the messages on the planchette board, the presence of a ghost is confirmed as Anna (Joanne Froggatt) and Daisy sit down to the abandoned game in the quiet servants' hall. The women accuse each other of forcing the indicator as it moves very deliberately to spell out 'May they be happy. With my love'. To confirm to the viewer that the spirit is that of the tragic Lavinia (Zoe Boyle), 
Matthew's dead fiancée, the scene cuts to Mary standing outside the grand entrance of the house. As snowflakes gently flutter and catch the pale light emanating from the windows, Matthew joins her and the couple make their declaration of love. Despite the cold evening, Mary insists that Matthew kneel in the snow and make a proper proposal. With her acceptance, they embrace, the music swells, and the camera pulls back to show the grand house in its wintry splendour.

In her five-star review for The Telegraph, Sarah Crompton described a 'remarkable return to form' with a love story as the perfect Christmas gift (2011). Alex Hardy's review for The Times was entitled 'Downton delivers a perfect Christmas treat' (2011), while Alison Graham in the Radio Times called it a 'terrific episode that crackles with life and rings with emotion' (2011). Ben Lawrence recalled that '[t]here was a picturesque flurry of snow, Christmas lights twinkled, and, if I'm not mistaken, angels descended from the skies and sang madrigals. It was a deeply satisfying episode for fans who had become anxious after the wonky, half-cooked storylines of series two' (2012). It seems that the programme had largely succeeded in winning over the British critics with its warm festive charms by meeting precisely the expectations of Christmas fostered within popular culture. The content, though, was an odd fit as a February season finale.

Rachel Syme for Time wrote that the episode was so satisfying in terms of the Matthew/Mary storyline that it felt like fan fiction and its original air date in the UK meant that it 'was especially well timed for extreme wish fulfilment' (2012). As Johnston has noted, though, the significance of the Ouija board was not recognized by US reviewers. Syme called it 'plain laziness' as a plot device (2012), while Fashion listed the game under the heading of 'Best Halloween Christmas prop' (Fashion Staff 2012). Johnston argues that while the supernatural has a place in American festive broadcasting, it is 'more closely related to questions of non-denominational faith, with the predominant focus of that being Santa Claus' 
(2015: 87). Hence, not only was Christmas in February anomalous, so too was the very British tradition of a ghost story for the festive season. Thematically, for Downton Abbey, this supernatural addition was also unusual, which supports Johnston's observation that seasonal specials can break rules to a certain extent (2015: 95). By contrast, a season finale should be entirely compatible with the season.

Subsequently it seems that the increasing appeal of the show in the US and the potential to capitalize on its rising popularity was not overlooked by Fellowes. Since the initial Christmas special there was a distinct move away from creating a seasonal celebration for British audiences that met preconceived expectations of the period to a practical season finale that brought some aspects to a close, but provided enough impetus for audiences to anticipate the next instalment.

\section{'A Journey to the Highlands' (2012)}

The British press's response to the programme continued to be varied. Gill's caustic response to the beginning of season three seethed with contempt. He attacked its predictability by likening it to a 'Women's Institute writing circle' and 'Neighbours in fancy dress' (Gill 2012). The UK viewing figures, contrary to the tepid critical reception, remained strong and, according to the Broadcasting Audience Research Board (BARB), had audiences of between 10.2 and 10.6 million per week during the course of the season. This was down on the high of just over 11.1 million for final episode of the second season, but was an improvement on the average audience (www.barb.co.uk/viewing-data/weekly-top-ten).

Before season three aired in the UK, the growing appeal of the programme in the US was evident in increasing viewing averages across the season from an opening of 4.2 million, culminating in it becoming the highest rated PBS show since 2009 with an average 5.4 
million viewers (O’Connell 2012). In February 2012 the BBC online news magazine reported a growing 'cult' of Downton emerging in the United States. Drawing upon social media, fan commentary and journalists, Brian Wheeler attempted to understand the following that the programme had already gained across Atlantic. Quoting Lisa de Moraes from The Washington Post he highlights a representation of a simpler, more stable time in a contemporary period of economic uncertainty as fundamental to its lure, while remarks from fans added a fascination with class, the biting wit of Dame Maggie Smith's Dowager Countess, and fairy tale escapism as central to its appeal (Wheeler 2012). A more deep-seated appreciation of British drama from an industrial perspective, though, can perhaps also be cited for the series' popularity. Elke Weissmann, in her discussion of transnational television, notes the impact of British drama as a benchmark that has been 'instrumental in carving out what was considered "quality" on US television' (2012: 171). For the programme itself from this point onwards, and especially with regards to the feature length festive episodes, cultivating the flourishing US popularity appears to have been prioritized by Fellowes, as the subsequent episodes demonstrate.

The episode opens 'one year later' (after the end of season three) and the household is bustling with activity. They are packing for a journey to Scotland to stay at Gleneagle Castle, home of the Marquess of Flintshire, Hugh 'Shrimpie' MacClare (Peter Egan), and his family. The significant moving of location is the novel aspect to this episode and is perhaps concession to the 'special' nature of it for UK audiences. Moving the family, except the struggling-to-fit-in widower and former chauffer, Tom Branson (Allen Leech), and some members of the household staff, north, enables a fetishistic emphasis on the procedures of packing and travelling by steam train. Once in Scotland the prominence of nostalgic reverie leads to beautiful shots of the glens, elegant rivers, majestic stags, interiors decorated with antlers, and a picnic on the shores of a loch. Bagpipes announce dinner and wake the guests 
in the morning, the gillie's lesson in stalking and honourably dispatching the game celebrates lapsed traditions, and the ball is brought to life with tartan, kilts and highland dancing. There is a melancholic undertone, however, as Shrimpie admits to Lord Grantham that not only is his marriage unhappy, he will lose the family estate because it failed to modernize, unlike Downton. This somewhat wistful emphasis on a disappearing past is congruent with Andrew Higson's observation that the fantasies of the national past found in 'heritage' productions are often set at times of change, and despite their sentimentality still feature the decline of a particular way of life. Higson points out, though, that the decline is offset by splendour and spectacular visual pleasures (2012: 619). Clearly the detailed and affectionate recreation of traditions and artefacts of the past are similarly mobilized within this episode, which is interesting in terms of the negotiations that the episode is attempting to achieve. On the one hand, it is a novel setting that offers new viewing pleasures to the UK audience, but on the other, being overtly steeped in the past acknowledges the growing US audience and the potential for escapism.

The nostalgic spectacle of the past is only one pleasure on offer to audiences. Chapman has argued that 'while the period mise-en-scène is recreated with all care and precision expected of the [costume drama] genre, it is rarely employed solely for pictorialist effect' (2014: 137). Instead, the beautiful visuals are 'balanced by a sense of closeness and intimacy that in its way owes as much to the tradition of studio-based drama as costume drama' (Chapman 2014: 138). This, coupled with the soap opera storylines and equal focus on the upstairs and downstairs contingents, marks a departure from the extravagant, but ultimately distancing narratives of the type of heritage films and television discussed by Higson. Indeed, the focus of this episode confirms its balance between visual nostalgia and intimacy. It is at once old-fashioned and familiar and sumptuous and excessive, which further evidences an attempt to make a quite awkward negotiation. 
In Yorkshire, the mood is lighter and the remaining servants take the opportunity to attend a late summer town fete. Mrs Patmore is wooed by caddish shopkeeper Mr Tufton (John Henshaw), the Downton team win a tug-of-war contest, and Dr Clarkson (David Robb) almost proposes to Isobel Crawley (Penelope Wilton). Ultimately, the episode contains a break from the norm which provides the novelty for the festive viewers, but it is lacking the warmth and cosiness of the first special and is far more perfunctory in nature. For instance, it provides a neat entrance for Lady Rose MacClare (Lily James) as a permanent cast member.

Most significantly, though, it hails the arrival of one heir and the death of another. Despite the concerns of the family and early labour, Mary gives birth to a boy, and Matthew tells his wife that despite his outwardly calm demeanour, he feels like he has 'swallowed a box of fireworks'. Unfortunately, his jubilance leads to reckless driving and he ends his journey off the road. The episode concludes with cuts from the Dowager commenting that 'we don't always get our just desserts', to a close-up of Matthew, obviously dead, with blood running down his face, to, finally, bathed in a soft glow, an almost divine mother and her child tableaux in the stark, white hospital room. The expressively lit scene perhaps recalls familiar Christmas imagery of the nativity, thus specifically evoking a sense of the season. Conversely the brutal despatching of Matthew with the family yet blissfully unaware is void of comfort and tonally feels far more finale than Christmas treat. Moreover, it signals a significant change that will impact on the central narrative of the show, and as such is an event that encourages an anticipation of 'what happens next?'

Serena Davies's review of the second Christmas special for The Telegraph barely mentioned the festive scheduling and concentrated instead on the loss of Stevens as a key cast member (2012). Viv Groskop in The Guardian argued that the slow-paced episode functioned as ominous prelude to Matthew's death, a device used previously in the lead-up to Sybil's untimely ending (2012). 
In her discussion of the changing tone of Downton Abbey, Katherine Byrne has argued that series three marked a shift in the nostalgic, harmonious paternalistic world originally fostered by the first two seasons. Interestingly, she notes that this highlights Fellowes's sensitivity to criticism and the altered socio-political and economic climate of the late 2000s:

Originally the drama rose to popularity alongside the newly elected Conservativedominated coalition government and offered a mix of soap opera detail and escapist fantasy to an audience in the grip of a worldwide recession. Perhaps in a response to the disillusionment that accompanies continued economic hardship, that fantasy has become more problematic and less rosy in the third and fourth seasons, however. (Byrne 2015: 179)

Drawing on some of the popular responses to the third and fourth seasons, Byrne comments on the relationship between the show and the public. She argues that the expectations of the audience for a 'certain type of entertainment and moral lesson' are more important than realism and hence the storylines that featured death and rape had a negative impact on the viewing figures and press responses (Byrne 2015: 182). The 'agreement' between the spectators and the creator is perhaps most sensitive in a seasonal episode because of the need to fulfil an idealized fantasy. As Whiteley puts it, 'Christmas brings with it a sense of "recognition" that is largely dependent on a sedimented evocation of history' (Whiteley 2008a: 2). Failure to engage with established traditions potentially renders something billed as a 'Christmas special' problematic.

As UK audiences levelled and then gradually began to fall, the US ratings continued to grow and season three ended on a high of 8.2 million for the Christmas-special-turnedfinale (O’Connell 2013). The responses to the episode in the United States, while comparable 
in their disappointment over the departure of Stevens, seemed more concerned that the season finale had been compromised by 'spoilers', not least by Stevens himself, who had widely discussed his decision to leave the show in interviews early in 2013. Tom Gilatto in People noted that the event was 'sadistically abrupt and arbitrary' and that overall it has been a 'terribly sad season' (2013), which distinctly links the episode to the rest of the season rather than separating it as a festive special. Sean T. Collins's thoughtful response in Rolling Stone observed: 'The show already had a subtly but noticeably different and darker energy postSybil's death; it's tough to imagine what it will feel like now that the anchor of both its main romantic and political dramas is dead' (2013). Despite scheduling making the impact of a surprise ending problematic, this review also seems to read the episode as consistent with the themes and tone of the season, rather than a stand-alone special. Both reviewers demonstrate clearly the difference between UK and US reception.

From a slightly different perspective, but also acknowledging a shift in the function of the second feature length episode, Meredith Blake in the LA Times stated that Fellowes used the episode to 'reset the show entirely' (2013). Perhaps further underlining the finale-feel of the show as opposed to a warming festive treat, the series executive producer Gareth Neame told the Hollywood Reporter: 'People were devastated. But it is the shocks and the surprises in this show that give it so much dramatic rocket fuel that we need to keep it compelling' (Wilson 2013: 10). The expressions employed here - 'shocks', 'surprises' and 'dramatic rocket fuel' - are far more in keeping with the tactics needed to keep audiences engaged and wanting more.

\section{'The London Season' (2013)}

If the first feature length episode was the most overt attempt to court the British critics, then the third was the most explicit acknowledgement of the American reception and the 
programme's status as a co-production with Masterpiece Theatre. Higson has pointed out that productions about England, English characters and English history have become a means to secure investment and audiences, and '[s]elling Englishness thus works as a reasonable business strategy, even if it is a specialist one' (2010: 25). James Leggott and Julie Taddeo have specifically noted that Downton Abbey has made 'careful address to international audiences' (2015: xvii). Such tactics were becoming increasingly apparent and were heightened in this episode with the inclusion of vibrant American characters. Alice Wright for the Metro called the episode overlong and laboured, and saved only by the tantalising display of affection between the stoic butler Carson (Jim Carter) and housekeeper Mrs Hughes (Phillis Logan) (2013). Ellie Walker-Arnott most explicitly remarked on the episode's failure to function as a Christmas special: 'You could argue that our expectations for TV on Christmas Day are set too high. But when the show is given such a big block of prime-time telly, it should be doing it justice' (2013).

As the episode opens, the family are once again preparing to leave, this time for London and the summer season of 1923, during which Rose will be presented at court. Attention is paid to already established plotlines, thus making it difficult to treat this as a stand-alone episode. For example, the suspicion surrounding Bates after the murder of his wife Anna's rapist builds when Mrs Hughes discovers a train ticket from York to London in the pocket of a coat that Anna has donated to a charity for Russian refugees, thus indicating that Bates was in the capital when the incident occurred. Mr Sampson (Patrick Kennedy), the devious poker player who was introduced earlier in the season, returns to cause anxiety when he steals a letter that could cause a ruinous scandal.

The customary forays into the traditions of the past are accentuated via the necessary pomp of the presentation of young women of notable birth at court followed by a debutant ball, executed fervently with elegant costumes and etiquette. Such moments are reminiscent 
of Higson's observations that heritage productions contain 'a fantasy of conspicuous consumption, a fantasy of Englishness, a fantasy of the national past' (2012: 607). Packaging Englishness in this way is especially useful in selling the programme to international markets.

The novelty of the episode is provided by the arrival of Lady Grantham's (Elizabeth McGovern) mother, Martha Levison, played with aplomb by Shirley MacLaine, and her delightfully cynical brother, Harold (Paul Giamatti). Much of the episode's humour is generated by the culture clash of Americans and high society London, and Fellowes savours sending up the stuffiness of the British when compared to the astute and worldly, but relaxed visitors. The easy manners and frank discourse brought by the American guests is light relief from the formalities and functions to expose the brittle façade maintained by the fading aristocracy. Even the Dowager, despite her typically biting comments, is upstaged when Mrs Levison turns down a proposal and accompanying title from Lord Aysgarth (Edward Fox), and observes that her world is getting closer, while the world of the past is slipping further and further away. Such celebration of a future in which titles means nothing and shrewd dealings and forthrightness are prized above pretence and decorum acknowledges the merits of an 'American way'.

Fellowes is clearly responding more overtly to the increasing audience across the Atlantic by incorporating enjoyable and memorable American characters who remain unaffected amid the fanciful and cosy nostalgia. It also ties more broadly to literary exploration of the lives of wealthy American women, 'buccaneers', marrying into aristocratic European families found in the work of authors such as Edith Wharton and Henry James. Furthermore, it is perhaps a prelude to Fellowes's potential project for NBC, The Gilded Age, a heritage drama set in 1880 s New York high society. Ultimately, the concession to comforting romance, the element seemingly most celebrated by the British press, is brief and delivered in the very final scene as Carson and Mrs Hughes take each other's hand as they 
paddle in a glistening south coast sea. While there may be family, communion and a sense of wish fulfilment here, there is an absence of a 'nexus of traditions' (that are as much aesthetic as ideological) advocated by Thompson as essential to seasonal viewing.

Season four seemed, overall, to have had a slightly harder time pleasing some of the US critics, although the final episode appeared to supply an agreeable conclusion. Youyoung Lee for the Huffington Post commented that 'the 90-minute finale, with its gorgeous gowns and magical ball and the arrival of some very special American guests, has surely restored faith again in our beloved British series' (2014). Gilatto called it a 'nice, gentle close to a difficult, unsatisfactory season' (2014), while Joanne Ostrow for The Denver Post remarked that it was a 'graceful season finale' (2014). In the spirit of an open-ended season finale that is a prelude to the next instalment, rather than a neat one-off episode, Joe Heim for The Washington Post questioned: "Wait, did the season finale of "Downton" leave us with more questions than it answered?' (2014).

\section{'A Moorland Holiday' (2014)}

In the UK in the run-up to the 2014 festive episode, Neil Batey for the Mirror bemoaned the lack of festive flavour in 2012 and 2013: 'There's only been one problem with recent Downton Christmas specials - they haven't been very Christmassy' (2014). In a Radio Times interview with Allan Leech in January 2014, it was suggested that the cast had begun campaigning for a Christmas-set special. It was prefaced by a short piece by Walker-Arnott who, like Batey, commented on the absence of a seasonal setting:

But, if you ask me, there was still something missing [from the previous Christmas specials]. You know, the Christmas tree, the carols, the banqueting table weighed down with Mrs Patmore's festive delights, the romantic proposals in winter coats as 
the snow swirls around the Abbey. (Now THAT was a proper Downton Christmas special.) (Walker-Arnott 2014)

The episode opens with Mary visiting Anna in prison. The maid has been arrested for the murder of her rapist. The bleak greys of the walls and bars are then intercut with the now habitual brightly lit scenes of the family busily preparing to leave Downton. The 1924 trip is to Brancaster Castle in Northumberland, which has been rented by Rose's new father-in-law, Lord Sinderby (James Faulkner), for an autumn grouse shoot. As with the second festive episode, there is considerable focus on traveling, accentuated by lingering shots of beautiful leather luggage and the opulence of the first-class carriages. There are numerous subplots crowding the episode, some of which reprise accustomed storylines, such as the humorous rivalry between the Dowager's butler Spratt (Jeremy Swift) and her lady's maid Miss Denker (Sue Johnston), and the long-standing saga of Anna and Bates takes on a new twist. Introductions are made too, in particular Bertie Pelham (Harry Haddon-Paton) and Henry Talbot (Matthew Goode) as potential partners for the Crawley sisters, and a permanent position as footman is secured for Andy (Michael Fox), a possible beau for Daisy.

The programme's packed agenda left only a little room at the end for a festive celebration, and the closing twenty-two minutes seemed only a small dispensation to the calls for a more Christmassy feel from the cast and journalists. However, there was certainly some attempt made to recapture the warmth of the 2010 episode with shots of a beautifully decorated tree, neatly wrapped presents and carols. Furthermore, the final moments included a heartfelt farewell to Tom (who is about to depart for America), a proposal by Carson to Mrs Hughes, and the safe return of Bates.

Gerard O'Donovan for The Telegraph appears to have been rather enchanted by the episode and wrote: 'The surprise marriage proposal to housekeeper Mrs Hughes (Phyllis 
Logan) was the enormous cherry on top of a Christmas special that was brimming with intrigue, warmth, sentiment and good cheer' (O'Donovan 2014). The brief Christmas interlude seemed perhaps too little, too late for other UK critics. Christopher Stevens noted that '[a]ll this felt like housekeeping, packing away old plots to make room for new ones next year' (2014). For Groskop the episode 'worked well as retro festive wallpaper', but proved that the series had 'outstayed its welcome' (2014). For US reviewers, the 'packing away' aspect of the show seemed to provide a satisfying and suitable conclusion to the season, even if it meant Christmas in the Spring. Brian Lowry for the Boston Herald commented: 'Taking the term "Christmas episode" to heart, series creator Julian Fellowes advanced so many storylines to satisfying points it frankly wouldn't have been a bad place to end the show entirely' (2015).

Downton Abbey's scheduling in the United Kingdom and United States was destined to create disparity. Just as the festive episodes where Christmas was absent seem to have prompted especially negative responses from the critics in the United Kingdom, the way in which the season finale was a 'bolt-on' episode in the United States threatened to be an awkward fit. In the episodes, Fellowes's efforts to negotiate problematic territory are evident. There have been palpable attempts to appease audiences and commentators both sides of the Atlantic, but with an increasing emphasis on capitalizing upon the US success through the shifts from overtly festive themes to summer seasons and Highland holidays and back again to December. They also, in their role as a season finale, need to create enough eagerness for the next season. Maria Ionita has argued that "[1]ong form serialization is driven by the apparently contradictory impulses of simultaneously anticipating and postposing a narrative climax' (2014: 23). Potentially this dynamic can enhance the drama of the storyline, but for Downton Abbey is complicated by the dual-nature of the episode. Additionally, as Weissmann observes, it is simply a more recent example of a long-standing tradition of US 
producers seeking to connect with the perceived 'cultural kudos' of UK sources and an existing relationship based on internationalization of labour and transnationalization of drama television (2012: 37-8). Furthermore, according to Weissmann, to be successful and maintain appeal outside the primary context of production, programmes must create an attraction of 'otherness' through cultural difference, but simultaneously be integrated into 'home' culture (2012: 39). Indeed, the consistent mediations made by Fellowes in the Christmas specials underscores the need to create attractions for a varied international audience.

\section{'The Finale' (2015)}

After considerable speculation in the press and on social media sites, Neame announced in March 2015 that the sixth season would be the last. The 25 December 2015 episode was the most watched drama on Christmas Day in the UK with figures of 6.9 million viewers reported (Radio Times staff 2015). Richard Vine for The Guardian lamented the coming to an end of a 'glorious fantasy of Britain' (2015). The fondness for the show, despite its uneven coverage in the British press, was echoed elsewhere with Neela Debnath for the Express calling it 'a satisfying close for a British institution' (2015), while Allison Pearson for The Telegraph admitted to having tears in her eyes as the much-loved characters sang Auld Lang Syne (2015). The episode was perhaps rather conceited and awash with happy endings for the central characters, but as a conclusion it operated successfully to draw the series to a close, and the festive setting suited the sentimentality of the farewells and the 25 December premiere.

Similarly, the US reviewers commented upon the neatness of the finale (which was screened in early March 2016). Mary McNamara for the Los Angeles Times wrote: 'If there 
has ever been a more wantonly happy-ending finale in the history of television, I have never heard of it. No ribbon was left untied, no tea cake unfrosted, no romantic possibility overlooked' (2016). Moreover, she concluded that '[c]elebrating all its fairy-tale confectionary without even an attempt to limit the sugar, "Downton Abbey's" final hour was shameless, ridiculous and absolutely glorious' (2016). Pertinently, Louis Bayard for The New York Times acknowledged the shift towards the American audiences. He argued that:

I think it's fair to say that Julian Fellowes has given us an American happy ending. And why shouldn't he? Haven't we loved these foolish Granthams with all the fervor of their countrymen? Don't we have the operational tear ducts to prove it? And when that Scottish songstress Mrs. H launched into Bobby Burns's old lyric “Auld Lang Syne," didn't we ache at the thought of leaving behind these silly, maddening, wonderful people? (2016)

The show's creator told USA Today that he wanted a 'warm ending', specifically: 'I wanted (viewers) to reach for their handkerchiefs in appreciation ... not because something ghastly had happened' (Keveney, 2016).

In many respects, the function of this episode was far simpler than that of the previous specials because less tension existed in terms of its purpose. Firstly, and fore mostly, it had to, for both audiences, provide a satisfactory end to the series. Martin Zeller-Jacques argues that contemporary 'high-end' serial television dramas rely on specific formal features, 'particularly reinscription of core relationships and the employment of music, to signify closure', together with 'performative excess' (2014: 119). Significantly, he proposes that ' $[\mathrm{t}]$ he melodramatic excess that characterizes many television endings thus often takes the form of an elaborate celebration of the semantic codes of the series, revisiting beloved characters and locations and emphasizing circularity rather than change' (Zeller-Jacques, 
2014: 120). The finale of Downton Abbey certainly adheres to these conventions by visually and thematically drawing together the much-loved and familiar characters in well-established settings. As the critics on both sides of the Atlantic noted, it was a cozy and satisfying conclusion that celebrated the engrained semantic codes of the show, and in keeping with Zeller-Jacques notion of circularity, the weddings, birth, new business ventures, all signaled continuance even though the audience were bidding farewell.

\section{Conclusion}

Downton Abbey's 'Christmas specials' provide an interesting opportunity to consider how a long-running series responds to trends in critical reception and the differing viewing patterns and cultural norms of transnational audiences as well as the tensions created by a dualfunction episode as seasonal edition and season finale. By concentrating on the show's primary markets, the United Kingdom and United States, it has been possible to chart how the episodes have attempted to negotiate, not always successfully, the anticipations of critics and audiences, a task that was especially difficult because of out-of-sync and differently structured scheduling. For British audiences, the Christmas special was not screened at the end of the season, but after a two-month break. For US audiences, it was positioned as the final episode, and there is evidence that Fellowes became increasingly mindful of its function as finale, and thus used it to further established storylines and enhance the drama in and anticipation of the next season. Additionally, it has become apparent that the expectations of the British press when it comes to seasonal programming are particularly high. Whiteley contends that Christmas is situated 'within an ideological discourse that centres on romantic idealism: a visionary, imaginative, descriptive expression of love which mobilises fantasy, myth and Christian belief through the production of cultural activities, rituals, customs and 
texts' (2009b: 99). Consequently, it seems that the absence of appropriately festive traditions and ideological underpinnings in a seasonally scheduled programme is licence for much harsher censure and reveals much about the persistent expectations tied to the period.

\section{References}

Bartel, J. (2015), “'Downton Abbey” Season 5 finale recap, A surprise engagement', The Baltimore Sun, 1 March 2015, http://www.baltimoresun.com/entertainment/bthesite/tvlust/bal-downton-abbey-season-5-finale-recap-a-surprise-engagement-20150301-story.html. Accessed 2 November 2015.

Batey, N. (2014), 'Downton Abbey Christmas special: The Crawley's head north as ITV brings back the festive feeling', Mirror, 20 December 2014, http://www.mirror.co.uk/tv/tvnews/downton-abbey-christmas-special-crawleys-4836628. Accessed 28 July 2015.

Bayard, L. (2016), “"Downton Abbey” Finale: A Grand British Story With an American Finish', The New York Times, 6 March 2016, http://www.nytimes.com/2016/03/06/arts/television/downton-abbey-finale-a-grand-britishstory-with-an-american-finish.html?_r=0. Accessed 19 November 2016.

Blake, M. (2013), ““Downton Abbey” recap: Ending on a (very) down note', Los Angeles Times, 18 February 2013, http://articles.latimes.com/2013/feb/18/entertainment/la-et-stdownton-abbey-recap-finale-matthew-death-20130217/2. Accessed 31 October 2015.

Brinker, F. (2015), 'On the Formal Politics of Narratively Complex Television Series: Operational Self-Reflexivity and Audience Management in Fringe and Homeland', in S.M. Herrmann, C.A Hofmann, K. Kanzler, S. Schubert and F. Usbeck (eds.), Poetics of Politics: 
Textuality and Social Relevance in Contemporary American Literature and Culture, Heidelberg: Winter Universitätsverlag, pp. 41-62.

Broadcasting Audience Research Board (BARB), Weekly Top Ten Programmes, www.barb.co.uk/viewing-data/weekly-top-ten. Accessed 10 December 2015.

Byrne, K. (2015), 'New Developments in Heritage: The Recent Dark Side of Downton “Downer" Abbey', in J. Leggott and J. Taddeo (eds.), Upstairs and Downstairs: British Costume Drama Television from The Forsyte Saga to Downton Abbey, New York and London: Rowman \& Littlefield, pp.177-190.

Chapman, J. (2014), 'Downton Abbey: Reinventing the British Costume Drama', in J. Bignall and S. Lacey (eds.), British Television Drama: Past Present and Future $2^{\text {nd }}$ Edition, Basingstoke: Palgrave McMillian, pp. 131-142.

Collins, S. T. (2013), “"Downton Abbey” Season 3 Finale recap: “I just can’t see a happy ending”, Rolling Stone, 17 February 2013, http://www.rollingstone.com/movies/news/downton-abbey-season-finale-recap-i-just-cantsee-a-happy-ending-20130217. Accessed 31 October 2015.

Crompton, S. (2011), 'Downton Abbey, Christmas Special, ITV1, review', The Telegraph, 25 December 2011, http://www.telegraph.co.uk/culture/tvandradio/downtonabbey/8975463/Downton-Abbey-Christmas-special-ITV1-review.html. Accessed 25 July 2014. 
Davies, S. (2012), 'Downton Abbey Christmas Special, review', The Telegraph, 25

December 2012, http://www.telegraph.co.uk/culture/tvandradio/downton-

abbey/9765378/Downton-Abbey-Christmas-Special-review.html. Accessed 17 October 2015.

Debnath, N. (2015), 'Downton Abbey finale episode TV review: A satisfying close to a British Institution', Express, 25 December 2015, http://www.express.co.uk/showbiz/tvradio/629426/Downton-Abbey-final-episode-TV-review-Michelle-Dockery-Lady-EdithHugh-Bonneville. Accessed 29 December 2015.

de Groot, J. (2009), Consuming History: Historians and heritage in contemporary popular culture, London and New York: Routledge.

Fashion Staff (2012), 'Downton Abbey recap: The Christmas special teaches us to confess our true love, use Ouija boards, pick up new parents and not to lock dogs in sheds', Fashion, 20 February 2012, http://www.fashionmagazine.com/scene/2012/02/20/downton-abbeyrecap-the-christmas-special-teaches-us-to-confess-our-true-love-use-ouija-boards-pick-upnew-parents-and-not-to-lock-dogs-in-sheds/6/. Accessed 21 October 2015.

Fellowes, J. (2011), 'My Downton Abbey Christmas', Radio Times, 23 December 2011, http://www.radiotimes.com/news/2011-12-23/julian-fellowes-my-downton-abbey-christmas. Accessed 29 November 2015.

Gilatto, T. (2013), 'Downton Abbey’s Season 3 Finale: Shocking', People, 17 February 2013, http://www.people.com/people/article/0,,20673834,00.html. Accessed 31 October 2015. 
Gilatto, T. (2014), 'Downton Abbey Finale: A Reassuring Ending for a Turbulent Season', People, 24 February 2014, http://www.people.com/people/article/0,,20789915,00.html. Accessed 31 October 2015.

Gill, A. A. (2011), 'Game over as toffs trump spies', The Sunday Times, 25 September 2011, http://www.thesundaytimes.co.uk/sto/culture/film_and_tv/tv/article780911.ece. Accessed 28 July 2015.

Gill, A. A. (2012), 'Anything might happen, but nothing will', The Sunday Times, 23 September 2012, http://www.thesundaytimes.co.uk/sto/culture/film_and_tv/tv/article1129037.ece. Accessed 30 July 2015.

Graham, A. (2011), 'Downton Abbey: Christmas special 2011', Radio Times, 25 December 2011, http://www.radiotimes.com/episode/n2r4t/downton-abbey--christmas-special-2011. Accessed 15 October 2015

Groskop, V. (2012), 'Downton Abbey: Plot moving slowly? It must be time for someone to die', The Guardian, 26 December 2012, http://www.theguardian.com/tv-andradio/2012/dec/26/downton-abbey-plot-time-die. Accessed 21 October 2015.

Groskop, V. (2014), 'Downton Abbey Christmas special recap - it worked well as retro festive wallpaper', The Guardian, 25 December 2014, http://www.theguardian.com/tv-andradio/tvandradioblog/2014/dec/25/downton-abbey-christmas-special-recap-it-worked-asretro-festive-wallpaper. Accessed 2 November 2015. 
Hardy, A. (2011), 'Downton delivers a perfect Christmas treat', The Times, 14 December 2011, http://www.thetimes.co.uk/tto/arts/tv-radio/article3257428.ece. Accessed 25 July 2015.

Heim, J. (2014), “"Downton Abbey” recap: The season finale, The Washington Post, 23 February 2014, https:/www.washingtonpost.com/news/style-blog/wp/2014/02/23/downtonabbey-recap-the-season-finale/. Accessed 31 October 2015.

Higson, A. (2010), Film England: Culturally English Filmmaking Since the 1990s, London: I.B. Taurus.

Higson, A. (2012), 'Re-presenting the National Past: Nostalgia and Pastiche in the Heritage Film', in B. K. Grant (ed.), Film Genre Reader IV, Austin: University of Texas Press, pp. $602-627$.

Ionita, M. (2014), 'Long-form Televisual Narrative and the Operatic Structure in Bryan Fuller's Hannibal', Cineaction, 94, pp. 22-28.

Johnston, D. (2015), Haunted Seasons: Television Ghost Stories for Christmas and Horror for Halloween, Basingstoke: Palgrave Macmillan.

Kamp, D. (2012), ‘The Most Happy Fellowes’, Vanity Fair, December 2012, http://www.vanityfair.com/culture/2012/12/julian-fellowes-downton-abbey. Accessed 17 October 2015. 
Keveney, B. (2016), 'Major milestones mark “Downton Abbey”finale', USA Today, 7 March 2016, http://www.usatoday.com/story/life/tv/2016/03/06/major-milestones-mark-downtonabbey-finale/81293896/. Accessed 19 November 2016.

Lawrence, B. (2012), 'Downton Abbey, ITV 1, review', The Telegraph, 16 September 2012, http://www.telegraph.co.uk/culture/tvandradio/downton-abbey/9546474/Downton-AbbeyITV1-review.html. Accessed 16 October 2015.

Lee, Y. (2014), “"Downton Abbey” Recap, Season 4 Finale: Princely Scandals and Mr. Carson's Ankles', Huffington Post, 23 February 2014, http://www.huffingtonpost.com/youyoung-lee/downton-abbey-recap-season-4finale_b_4825356.html. Accessed 31 October 2015.

Leggott, J. and Taddeo, J. A. (2015), 'Introduction', in J. Leggott and J. Taddeo (eds.), Upstairs and Downstairs: British Costume Drama Television from The Forsyte Saga to Downton Abbey, New York and London: Rowman \& Littlefield, pp. xv-xxx.

Lowry, B. (2015), “'Downton Abbey” finale takes 'Christmas episode' to heart', Boston Herald, 2 March 2015, http://www.bostonherald.com/entertainment/television/television_reviews/2015/03/downton_ abbey_finale_takes_christmas_episode_to. Accessed 2 November 2015.

McNamara, M. (2016), “'Downton Abbey” gives fans a feel-good finale', Los Angeles Times, 6 March 2016, http://www.latimes.com/entertainment/tv/la-et-st-downton-finale-review20160307-column.html. Accessed 19 November 2016. 
O’Connell, M. (2012), “'Downton Abbey” Season 2 Finale Marks PBS' Highest-Rated Program Since 2009', The Hollywood Reporter, 23 February 2012, http://www.hollywoodreporter.com/live-feed/downton-abbey-season-2-finale-ratings294575. Accessed 19 October 2015.

O’Connell, M. (2013), ‘TV Ratings: “Downton Abbey” Finale Rises to Record 8.2 Million Viewers', The Hollywood Reporter, 19 February 2013, http://www.hollywoodreporter.com/live-feed/tv-ratings-downton-abbey-finale-422335. Accessed 19 October 2015.

O’Donovan, G. (2014), 'Downton Abbey, Christmas Special, review: “He did it!”, The Telegraph, 25 December 2014, http://www.telegraph.co.uk/culture/tvandradio/downtonabbey/11310458/downton-abbey-christmas-review-2014.html. Accessed 2 November 2015.

Ostrow, J. (2014), “'Downton Abbey” season 4 finale’, The Denver Post, 23 February 2014, http://blogs.denverpost.com/ostrow/2014/02/23/downton-abbey-season-finalespoilers/18006/. Accessed 31 October 2015.

PBS Press Release (2014), “"Downton Abbey Season 4” Finishes Strong on MASTERPIECE with 8.5 Million Viewers', PBS, 24 February 2014, http://www.pbs.org/about/news/archive/2014/downton-abbey-4-finale/. Accessed 28 July 2014. 
Pearson, A. (2015), 'Downton Abbey, Christmas Special, review: "a fond farewell"', The Telegraph, 25 December 2015, http://www.telegraph.co.uk/culture/tvandradio/downtonabbey/12065947/Downton-Abbey-Christmas-Special-review-a-fond-farewell.html. Accessed 29 December 2015.

Radio Times staff (2015), 'Downton Abbey is the most-watched show of Christmas Day 2015', Radio Times, 27 December 2015, http://www.radiotimes.com/news/2015-1227/downton-abbey-is-the-most-watched-show-of-christmas-day-2015. Accessed 28 December 2015.

Schama, S. (2012), 'Why Americans have fallen for snobby "Downton Abbey"', Newsweek, 16 January 2012, http://europe.newsweek.com/why-americans-have-fallen-snobby-downtonabbey-64157. Accessed 20 September 2015.

Stevens, C. (2014), 'Look out my lord, they're gunning for your drinks', Daily Mail, 26 December 2014, http://www.dailymail.co.uk/tvshowbiz/reviews/article-2887284/Look-lordgunning-drinks-CHRISTOPHER-STEVENS-reviews-Downton-Abbey-ChristmasSpecial.html. Accessed 17 October 2015.

Syme, R. (2012), 'Downtown Abbey Watch: Life is a Game, Time, 20 February 2012, http://entertainment.time.com/2012/02/20/downton-abbey-watch-life-is-a-game/. Accessed 21 October 2015. 
Thompson, R.J. (2005), 'Consecrating Consumer Culture: Christmas Television Specials', in B.D. Forbes and J.H. Mahan (eds.), Religion and Popular Culture in America revised edition, Berkley, Los Angeles, London: University of California Press, pp. 44-55.

Tincknell, E. (2013), 'Dowagers, Debs, Nuns and Babies: Nostalgia and the Older Woman in the British Sunday Night Television Serial', Journal of British Cinema and Television, 10:4, pp.769-784.

Vine, R. (2015), 'Downton Abbey review: the glorious fantasy of Britain comes to an end', The Guardian, 26 December 2015, http://www.theguardian.com/tv-andradio/2015/dec/26/downton-abbey-christmas-special-review-glorious-fantasy-britain-comesto-an-end. Accessed 28 December 2015.

Walker-Arnott, E. (2013), 'Downton Abbey: even in the season of excess the Christmas special was too long', Radio Times, 25 December 2013, http://www.radiotimes.com/news/2013-12-25/downton-abbey-even-in-the-season-of-excessthe-christmas-special-was-too-long. Accessed 31 October 2015.

Walker-Arnott, E. (2014), 'Downton Abbey's Allen Leech: We are aiming for a Christmas special set at Christmas this year', Radio Times, 29 January 2014, http://www.radiotimes.com/news/2014-01-29/downton-abbeys-allen-leech-we-are-aimingfor-a-christmas-special-set-at-christmas-this-year. Accessed 2 November 2015.

Weissmann, E. (2012), Transnational Television Drama: Special Relations and Mutual Influence between the US and the UK, Basingstoke: Palgrave Macmillan. 
Wheeler, B. (2012), 'The US cult of Downton Abbey', Magazine, 1 February 2012, http://www.bbc.co.uk/news/magazine-16731254. Accessed 17 October 2015.

Whiteley, S. (2008a), 'Introduction', in S. Whitely (ed.), Christmas, Ideology and Popular Culture, Edinburgh: Edinburgh University Press, pp. 1-16.

Whiteley, S. (2008b), 'Christmas Songs - Sentiments and Subjectives', S. Whitely (ed.), Christmas, Ideology and Popular Culture, Edinburgh: Edinburgh University Press, pp. 98112.

Wilson, S. (2013), 'Emmys: “Downton Abbey” Stars Reflect on the Bloody, Deadly Third Season', Hollywood Reporter, 16 August 2013, http://www.hollywoodreporter.com/news/emmys-downton-abbey-stars-reflect-606508. Accessed 4 August 2015.

Wright, A. (2013), 'Downton Abbey Christmas special 2013: Overly long festive edition felt slow and laboured but Carson and Mrs Hughes saved the day', Metro, 25 December 2013, http://metro.co.uk/2013/12/25/downton-abbey-christmas-special-2013-overly-long-festiveedition-felt-slow-and-laboured-but-carson-and-mrs-hughes-saved-the-day4234275/\#ixzz3q9j1vbjg. Accessed 31 October 2015.

Zeller-Jacques, M. (2014), 'Don’t Stop Believing: Textual Excess and Discourses of Satisfaction in the Finale of The Sopranos', M. Stewart (ed.), Melodrama in Contemporary Film and Television, Basingstoke: Palgrave Macmillan, pp. 114-129. 


\section{Television Programmes}

Breaking Bad (2008-2013, High Bridge Productions, Gran Via Productions, Sony Pictures Television)

Call the Midwife (2012- ,Neal Street Productions, BBC)

Downton Abbey (2010-2015, Carnival Film and Television, Masterpiece Theatre)

Mad Men (2007-2015, Lionsgate Television, Weiner Brothers, AMC, U.R.O.K. Productions)

The Waltons (1971-1981, Lorimar Productions)

\section{Biography}

Andrea Wright is a senior lecturer in Film Studies at Edge Hill University. Fantasy/fairy tales, New Zealand cinema, and television costume drama are central to her research interests. She has written on production design in The Company of Wolves and Legend for the collection Postmodern Reinterpretations of Fairy Tales; the problematic representation of women and the female body in sword and sorcery cinema for the Journal of Gender Studies; Hercules, landscape, identity and New Zealand for The Australasian Journal of Popular Culture; and adaptation, representation and national identity in The Quiet Earth for the collection Science Fiction Across Media. Her most recent publications include essays on gender representation in Snow White: A Tale of Terror, and The Paradise and Mr Selfridge, and she is currently working on articles on the New Zealand films Boy and What We Do in the Shadows. 